\title{
Proofs, Defenses, and the Determination of Guilt or Innocence
}

Medieval legal theory generally recognized three grades of proof: full proofs (probatio plena), which could alone offer complete proof; imperfect proofs (probatio semiplena), which were strong pieces of proof, but not strong enough to stand alone as grounds for conviction; and circumstantial evidence (indicia), which was clearly inferior and which alone could only rouse suspicion, not determine guilt. ${ }^{1}$ Inquisitorial procedure freed magistrates to consider many kinds of proofs, especially circumstantial evidence (indicia), ${ }^{2}$ and fama could serve as partial proof. ${ }^{3}$ A hierarchy of proofs ranged from irrefutable proof (confession), to full and certain proof (two eyewitnesses); half-proofs, which could be compelling pieces of witness testimony or strong circumstantial evidence, and quarter-proofs or uncertain proofs. ${ }^{4}$ This last category was the most common, and was particularly useful in all manner of cases because it was more flexible. In the courts, indicia were the most common sort of proof. ${ }^{5}$

This system of statutory proofs grew in the ius commune and thus was widely applicable, but even so it is difficult to say how judges reached their conclusions, and hard to know how strictly this hierarchy was applied in practice. In Florence, statutory requirements for proof appeared to largely remove judicial discretion from the determination of guilt or innocence, but in practice, there was no clear measure of the quality of these proofs or rules for their combination, and judges held a great deal of discretion in evaluating evidence. ${ }^{6}$ In Reggio, the statutes address only occasionally issues of proof, and not in a consistent manner.

1 Lévy, La hiérarchie des preuves, 28-29.

2 Langbein, Torture and the Law of Proof, 6-8.

3 Stern, "Public Fame in the Fifteenth Century," 198-222.

4 The standard work on proofs in medieval law remains Lévy's 1939 study, La Hiérarchie des preuves.

5 Massimo Vallerani, "Procedure and Justice," 52-53.

6 Stern, Criminal Law System, 31-32.

(C) Joanna Carraway Vitiello, 2016 | DOI 10.1163/9789004311350_006

This is an open access title distributed under the terms of the Creative Commons AttributionNoncommercial-NonDerivative 3.0 Unported (CC-BY-NC-ND 3.0) License, which permits any noncommercial use, and distribution, provided no alterations are made and the original author(s) and source are credited. 
This chapter explores the proof presented to the judges at Reggio, and defendants' efforts to rebut that proof. Virtually all evidence that came before the judge was in the form of witness testimony-physical evidence was very rare. Expert testimony in the form of medical consilia and the testimony of physicians had a different status than regular witness testimony. The defendant's confession constituted a certain proof, but even a confessed defendant had the right to make a defense, as we will see. When defendants tried to defend themselves from the charges against them, their defenses almost always took the form of a legal objection to the witnesses on the basis of their fama.

\section{Full and Certain Proof: Confession and the Problem of Torture}

Confession constituted an irrefutable full proof. The rate of confession when suspects appeared before the court at Reggio was very high. Of a sample of 362 cases where the accused was not contumacious (there was a contumacy rate of almost 50 percent in the criminal court of Reggio Emilia), 73 percent confessed to the charges against them. This is rather more than at Florence, where data from condemnation records suggests that about 37 percent of defendants who appeared in court confessed. ${ }^{7}$

The status of confession as the "queen of proofs" 8 combined with the judge's authority to use torture presented a danger that was not unrecognized by jurists, who devised rules for its implementation. Following Roman law, the civilians allowed torture and entrusted the judge to use his discretion (arbitrium) to employ this tool with moderation. ${ }^{9}$ Jurists tended to handle the question with care, recognizing together with Ulpian that torture is a "delicate and dangerous thing, eluding truth" ( fragilis et periculosa res, et fallens veritatem). ${ }^{10}$ Jurists encouraged judges to use great restraint in the application of torture. Mario Sbriccoli departed from scholars who saw these exhortations as cynical or even hypocritical, remarking that the jurists were trying to guard against

Stern's sample of 177 condemnations yielded 75 contumacious defendants. Of those that appeared, 64 denied the charges against them and 38 confessed. As at Reggio, confession could result from the desire for a reduced penalty, but in Florence most were obtained under torture; Stern, Criminal Law System, 210-211.

8 Langbein, Torture and the Law of Proof, 4.

9 Piero Fiorelli, La tortura giudiziaria nel diritto comune, vol. 2 (Giuffrè, 1954), 161-162.

10 Sbriccoli, “'Tormentum idest torquere mentem,' "19. 
the devastation that unrestrained torture would bring to the justice system. ${ }^{11}$ It was not just in the degree of torment that the judge's discretion came into play: perhaps more importantly, the judge also had discretion to determine whether enough circumstantial evidence existed to warrant subjecting the accused to torture at all. ${ }^{12}$ Once again, fama could play a role in this decision. But according to Gandinus, evidence gained under torture was not fully probative, and in any case, the evidence required to put someone to the torture was not radically different from evidence required for a conviction. ${ }^{13}$ To guard against coerced confessions, jurists required that confessions made under torture in order to be valid had to be repeated when the fear of torture had passed. However, although a confession made while under torture was not a full proof, it did constitute further indicia, which could allow defendants to be tortured again, should they recant their confessions. ${ }^{14}$

The degree to which learned discussions of torture affected practice by the courts is an open question, ${ }^{15}$ and the perimeters for the implementation of torture were set forth in municipal statutes, meaning that once again, there could be a great deal of local variation. It was not uncommon for statute law to strongly limit the instances in which torture was permissible. At Vercelli, a 1241 statute declared that no citizen could be tortured; in Bologna, the 1288 statutes forbade the torture of members of the popolo without the express permission of the Capitano della Città; in Chieri, citizens could not be put to torture under the 1311 statutes. ${ }^{16}$ In late medieval Florence torture was allowable only for certain crimes, including highway robbery, thefts committed at night (the commission of crimes at night was often an aggravating circumstance), arson, homicide, and the rape of an honest woman, as well as crimes like moneyclipping and treason. ${ }^{17}$ Exemptions from torture for citizens or magnates declined during the late middle ages, perhaps as torture became an established

11 Sbriccoli, "'Tormentum idest torquere mentem," 27. "Ipocrita, ribattono altri, se non cinico: fatto di reticenze, connivenze, pasticci argomentativi e sottigliezze sospette. A me sembra un atteggiamento di cautela garantista, vòlto a scongiurare la devastazione processuale che sarebbe seguita ad uso non frenato della violenza possible."

12 Fiorelli, La tortura giudiziaria, 163-164.

13 Vallerani, "Procedure and Justice," 53.

14 Edward Peters, Torture (Oxford: Blackwell, 1985), 57.

15 Peters, Torture, 62. For a thorough discussion of the problems of status and torture, see Blanshei, Politics and Justice, 320-322, which explores the role of privilege in exemptions to torture, and presents a different perspective from Fiorelli's observations that statutes generally limited torture to those of mala fama.

16 Pennington, The Prince and the Law, ${ }^{15}{ }^{-59}$.

17 Stern, "Politics and Law in Renaissance Florence and Venice," 217. 
component of legal procedure, to be used for crimes that could be punished corporally. ${ }^{18}$ At Reggio Emilia in the late fourteenth century, the judge's authority to torture the defendant depended upon the severity of the crime, not upon the person's status. Reggio Emilia's statutes dictated that torture could be used in cases of certain major crimes, including robbery, highway robbery, homicide, arson, patricide, "adultery" (which category could also include rape and abduction), incest, falsity, theft, or violence, or in the case of other serious crimes (alio gravi et enormi delicto). ${ }^{19}$ This last category would seem vague enough to perhaps allow torture in almost any violent crime. Indeed, one of the few trials that indicates the use of torture at Reggio concerned an assault. ${ }^{20}$

Fama was central to determining who could be subjected to torture. When the degree of the crime was established, the investigating official could resort to torture if legitimate circumstantial evidence, legitima indicia vel probationes, existed concerning the bad fama of the accused, and of his or her alleged misdeed. ${ }^{21}$ During the examination, the presence of two reliable notaries (duo notarii de melioribus et legalioribus) from the office of the Podestà was required. Their duty was to record everything said while the accused was being tortured or threatened with the fear of torture, under the penalty of fifty-five pounds if the notary should record anything other than what the accused said. The $1335 / 71$ redaction of the statutes states further that during the torture,

18 Peters, Torture, 50-57.

19 ASRe, Comune, Statuti del 1335/1371, fols. 25v-26v and ASRe, Comune, Statuti del 1392, fols. $147 \mathrm{~V}-148 \mathrm{r}$. There is no significant difference between the two redactions. The $1335 / 1371$ text reads: "Statuimus et ordinamus quod potestas vel eius iudices vel milites vel alter eorum vel aliquis rector seu officialis communis Regii vel aliquis de ipsorum famulis non possint nec debeant aliquem ponere vel poni facere in tormentis vel sub tormentis corde vel alicuius alterius generis tormentorum occasione alicuius maleficii vel delicti vel de quo esset aliquis accusatus vel denunciatus vel inquisitus vel alicuius alterius occasione vel que dici vel excogitari posset nisi ille vel accusatus vel denunciatus vel inquisitus esset accusatus vel denunciatus vel inquisitus de latrocino vel robaria strate vel prodictione civitatis vel castri vel alterius singularis persone vel de homicido incendio et patricidio vel adulterio vel incestu vel falsitate vel furto vel violentia vel alio gravi et enormi delicto. Et tunc possint poni ad tormenta si legittima procedant indicia vel probationes contra eum de mala fama sua et etiam de delicto de quo esset accusatus vel denunciatus vel inquisitus..."

20 ASRe, Giudiziario, Libri delle denunzie, March 6, 1389, vol. 13, fols. 44r-45r.

21 ASRe, Comune, Statuti del 1335/1371, fols. 25v-26v and ASRe, Comune, Statuti del 1392, fols. 147v-148r: "Quod nullus possit subici tormentis per potestatem, vel rectorem, vel aliquem de sua familia nisi secundum formam infrascriptam, et quis modus in hoc sit servandus, et de pena contrafacientium. Rubrica." BSR, Statuti, ms. 77, 69r: "Qualiter et quando quis possit et debeat subici tormentis." 
only the Podestà or his judges, the two notaries, and four messengers (nuncii) from the commune could be present. The 1335/71 redaction forbids all others from attending an examination under torture, but that clause was omitted in the 1392 redaction..$^{22}$ Considering that in Perugia a century earlier, the injured party or his relatives was required to attend the torture sessions, this relatively private interrogation emphasizes the authority of the court over the "conflictual" start of inquisitions in Perugia. ${ }^{23}$ The 1411 redaction requires the presence of the Podestà and the iudex maleficorum and his notary at the interrogation but does not mention the presence or absence of others. ${ }^{24}$

In all cases other than those that met the criteria set forth in the statutes, the Podestà or his officials were to continue their examination to its conclusion without torture, relying on whatever proofs were available to them. The judge did not have arbitrium in the use of torture. The only exception occurs in the 1411 redaction, which allows the Podestà "full and free discretion to inquire, proceed and punish, just as seems [best] to him" in prosecuting the "abominable vice of sodomy, on account of which the wrath of God unfurls against the sons of diffidence."25 That sodomy would be the one crime against which all measures could be used for discovering and prosecuting is not surprising. The fifteenth century saw in Italy a rapid growth in concern with sodomy, which incurred the death penalty in Venice, ${ }^{26}$ and in Florence because the target of a tribunal specifically developed to investigate it. ${ }^{27}$

The penalty for any judge or official using unauthorized torture was sharptwo hundred pounds, to be paid from the personal assets of the offending official. The official would also be required to make restitution to the person suffering injury as a result of illegal torture. However, the standard of proof for convicting the Podestà or his officials of such a crime was very high: the statutes required depositions from four citizens of high standing concerning the public vox et fama of the charge. It is difficult to know how often such accusations were made because such charges would likely have occurred during the

ASRe, Comune, Statuti del 1335/1371, fol. 26r. "Alii autem familiares potestatis vel alique alie persone non possint nec debeant inter esse dictis tormentis aliquot modo vel ingenio."

23 Vallerani, "How the Inquisition is Constructed," 255.

24 BSR, Statuti, ms. 77, 69r.

25 BSR, Statuti, ms. 77, 69r: “... arbitrium plenum et liberum inquirendi procedendi et puniendi prout eis videbitur... abhominabile vitium sodomie propter ira Domini Dei renit in filios diffidentie..."

26 Patricia H. Labalme, "Sodomy and Venetian Justice in the Renaissance," in Tijdschrift voor Rechtsgeschiedenis 52 (1984): 217-254.

For a study of this tribunal and its activity see Rocke, Forbidden Friendships. 
syndication of the Podestà, and records for that process survive only in the most fragmentary way.

While the statutes set forth clear rules for the situations in which torture could be used, we still should question the interpretation of those rules, or whether the judge sometimes used arbitrium not conceded to him in the statute. For example, in 1403, Johannes de Cuvriacho and Antonius Tramalius had a violent quarrel in which Antonius caused Johannes a fairly serious injury, striking him twice in the face, knocking out a tooth and causing an effusion of blood. He also threw Johannes to the ground and struck him with his knees. Johannes in turn was accused of striking Antonius with a stone, but this assault did not draw blood. ${ }^{28}$ Antonius was contumacious, but Johannes answered the citation and denied the charges made against him. He was summoned to answer the indicia against him, which consisted of the testimony of one eye-witness.

The denunciation specifically and repeatedly states that Johannes hit Antonius without drawing blood, and the testimony of one witness survives, who also said that the blow that Johannes gave to Antonius was done sine sanguine. It is hard to see how this met the criteria given in the statute, unless it met the vague category of violentia, even in the absence of bloodshed. Johannes entered legal exceptions to the charge, avoiding torture by impugning the fama of this witness. And yet, though Johannes entered a legal exception against the witness, he did not make an objection based on the statutes' perimeters for the use of torture. It is difficult to know why his advocate did not object on this ground: was the injury more severe than the records indicate? Or was the category of violentia really so widely interpreted? The outcome of this case is not known, but it is significant that Johannes could be summoned to torture for what appears to have been a relatively minor offense.

The evidence from torture sessions was not compiled inside the trial records in any systematic way, so it is difficult to gauge how often torture was used. Laura Stern, in her study of the criminal justice system in Florence, concluded that torture was used to elicit confessions in roughly 20 percent of the cases she surveyed. ${ }^{29}$ At Reggio Emilia, it is impossible to give with confidence an

28 ASRe, Giudiziario, Libri delle denunzie, November 3, 1403, and following days, vol. 20,

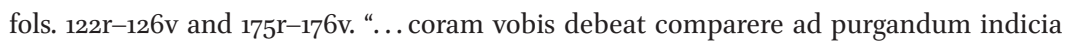
per torturam que habeat dictus Dominus Vicarius contra ipsum Johannem occaxione cuiusdam formate inquisitione contra eum eo quod percussit Antonium Tramalum aliax [sic] dictum Patagnonum con uno lapide quem dictus Johannes in suis manibus habebat una percussione in pectore dicti Antonii sine sanguine..."

Stern, Criminal Law System, 29 and 211-213. 
estimate of the frequency with which judges resorted to torture. Very few trials make reference to torture. Those that do include two cases of assault, ${ }^{30}$ two of rape, ${ }^{31}$ and three of murder. ${ }^{32}$ The judicial archive does contain some other sparse evidence of torture, including a badly damaged document, which records an interrogation in which the defendant was subjected to torture three times in spite of his repeated protestations of innocence, ${ }^{33}$ a directive to torture, and another investigation which recorded the use of torture. ${ }^{34}$ When this evidence can be matched with a trial, it quickly becomes apparent that trial records do not always reflect torture even when it was clearly used.

The records of inquisition trials preserved in the Libri delle denunzie did not include torture interrogations as a matter of course, just as they did not include other investigative activity. When torture is mentioned inside criminal trials, it is in reference to another issue: efforts to impugn the fama of a witness, anecdotal references inside testimony, or even as the basis for the defendant's absolution after denial of charges under torture. Mentions of the practice are brief and unsystematic, and offer little insight into the use of torture or the frequency of its application.

Anecdotal references inside testimony may add some dimension to our understanding of torture in the courts. One interesting reference to torture occurs inside a murder trial, in which a certain Antonius Radi of Vidrianno was charged by Guido da Fogliano with murdering Daninus de Maxlio, one of Guido's men. ${ }^{35}$ According to the denunciation, Antonius with some of his associates went to the home of Daninus, broke down the door, and beat Daninus to death. Antonius then turned to Dominica, Daninus's wife, struck her, and said, "Whore, what do you know? Give me Daninus's money, or you

30 ASRe, Giudiziario, Libri delle denunzie, March 6, 1389, vol. 13, fols. 44r-45r; ASRe, Giudiziario, Libri delle denunzie, November 3, 1403, vol. 20, fols. 122r-126v, 175 r-176v.

31 ASRe, Giudiziario, Libri delle denunzie, June 9, 1388, vol. 10, fols. 27r-29r; ASRe, Giudiziario, Libri delle denunzie, April 5, 1396, vol. 15, fols. 4or-67v.

ASRe, Giudiziario, Libri delle denunzie, January 18, 1387, vol. 17, fols. 8r-13r; ASRe, Giudiziario, Libri delle denunzie, July 10, 1396, vol. 15, fols. 105r-113v; ASRe, Giudiziario, Libri delle denunzie, September 10, 1397, vol. 17, fols. 8r-13r.

ASRe, Giudizario, Atti e processi, August 26, 1396. The defendant was Andreas de S. Martino, discussed in Chapter Three.

34 ASRe, Giudizario, Atti e processi, n.d. 1374, fol. $161 \mathrm{r}$ and 1379, fols. 605r-6o6v.

35 ASRe, Giudiziario, Libri delle denunzie, September 10, 1397, vol. 17, fols. 8r-13r. This document is discussed more fully in Chapter Five in relation to the instrumentum pacis. On this episode see also Dean, "It's a fine thing trusting in you, Guido!" 
will die." ${ }^{36}$ Dominica directed him to a place under the threshold of the door, where Antonius found fifty-five gold florins, which he then stole.

What makes this case remarkable is not the alleged crime itself but the extraordinary measures Guido da Fogliano took to see it punished. When Guido asked the Capitano del devieto, Carolus de Guarchi, to do justice in this case, Carolus responded that "he was prepared to do justice for him if he gave him proof or circumstantial evidence, on account of which he could have him put to torture." 37 It was at this point that things took a turn to the bizarre. Guido asked Carolus to conceal himself behind a curtain to overhear a false peace negotiation, which Carolus could then use as indicia to put Antonius to the torture. This unusual arrangement is discussed more fully in the next chapter as it relates to peace negotiations, but here, it is significant that Carolus clearly assumed that to do justice necessarily meant putting the accused to the torture, and he had a specific idea of probationes et indicia required to proceed.

Perhaps even more telling is the reaction of Antonius's friends, when they learned that he confessed without torture. Petrezolus, the blacksmith of S. Paolo, went to Antonius, who was then being held in the home of Carolus, and said. "Oh you wretch, I heard that you confessed everything to Carolus without being tortured ... why did you not send yourself out to the torture, and if you felt that you had committed anything against Guido, why did you not tell your friends, who would find a way [to help you]?"38 Not realizing Antonius had been duped, his friend clearly thought he should have taken his chances under torture, not simply confessed before it began. Ultimately it is doubtful that his friend's advice would have done him much good. The criminal judge at Reggio interrogated him under torture, and Antonius confessed his crimes.

Strikingly, some jurists considered torture to be a right: defendants should be able to offer themselves to torture, if they wished, in order to purge the

36 ASRe, Giudiziario, Libri delle denunzie, September 10, 1397, vol. 17, fols. 8r-9v: "[Antonius] accessit ad Dominicham uxorem dicti Danini et ipsam percussit dicens, 'meretrix, que tues? Dote me denarius Danini aliter ex [sic] mortua,' que Dominicha videns sic se alteratus dixit eidem Antonio, 'prospice sub limine hostii ubi truet [sic] pecunas suas.' ”

37 ASRe, Giudiziario, Libri delle denunzie, September 10, 1397, vol. 17, fol. 9v “... qui Carolus respondit quod erat paratus ius facere si daret sibi probationes vel indicia propter que posset ipsum ponere ad torturam..."

38 ASRe, Giudizario, Libri delle denunzie, September 10, 1397, vol. 17, fols. 9r-10v: "O pessime, ego intelexi quod tot et tanta confessus fuisti sine tortura Carolo praedicto ... quare non dimitebas te torquere et si sentiebas et aliquid comisisse contra dictum Guidonem quare non dicebas amicis tuis qui reperissent modum?" 
evidence against them. ${ }^{39}$ But influential jurists like Bartolus and Francesco dal Bruno opposed this idea, on the grounds that this right constituted abandoning to private parties the power of torture, which was something that fell under the imperium of the government. ${ }^{40}$ Petrezolus's comment to the condemned Antonius shows that torture was understood as a window to absolution, if one could manage it: "why did you not send yourself out to the torture?"

It seems strange to consider torture a right. Yet it is worth remembering that a defendant who denied his guilt successfully under torture had to be absolved, and judges may not have found torture to be the expedient in gathering confessions that it is usually assumed to be. Of nine defendants that the records clearly indicate were tortured and whose outcome is known, only one was convicted. This is striking when we remember that the overall conviction rate in Reggio's criminal court was 89 percent. Defendants could and did deny under torture and earn absolution. Is this a statement about the degree of torture employed (or how consistent it was)? Should we consider arguments about the experience of pain in the pre-modern world, in which, without the modern benefit of surgical anesthesia and over-the-counter medications, terrible pain was perhaps not such an uncommon experience? ${ }^{21}$ Certainly among the rules that governed torture in juridical discussions were the requirements that it should not be disfiguring or permanently debilitating, and that its application must be limited. Yet our records reveal torture sessions in which the defendant was repeatedly tortured with different devices on the same day, and we should not be quick to think that torture as the court applied it was anything less than agonizing.

But in practice, the lack of clear rules - or perhaps more importantly, the lack of accountability - may well have led to inconsistencies, and judicial discretion not conceded by the statute. It is impossible to know with any certainty how often people confessed under torture, and whether it was commonplace. We simply do not have the evidence to make wide conclusions. The sporadic and fragmentary evidence that does survive, combined with the wide powers allowed to the judge to proceed with torture in major crimes, may suggest its frequent use; the relatively low conviction rate it yielded might suggest

39 Fiorelli, La tortura giudiziaria, 167.

$40 \quad$ Fiorelli, La tortura giudiziaria, 168.

41 Esther Cohen, "To Die a Criminal for the Public Good: The Execution Ritual in Late Medieval Paris" in Law, Custom, and the Social Fabric in Medieval Europe: Essays in Honor of Bryce Lyon, eds. Bernard S. Bachrach and David Nicholas (Studies in Medieval Culture, XXVIII) (Kalamazoo: Medieval Institute Publications, 1990), 285-304. 
hesitancy. The statutes tell us only that the judge had the authority to proceed; the court records reflect only inconsistency in recording the practice.

\section{Testimony and Witnesses}

It is often remarked that the Romano-canonical trial process changed the format of the trial from a confrontational theater between feuding parties to a more bureaucratic process, much of it conducted in writing. ${ }^{42} \mathrm{~A}$ hundred years earlier in Milan, written documentation submitted to the judge was very common and depositions of witnesses were somewhat rare. ${ }^{43}$ But in Reggio, depositions of witnesses before the judge were a necessary part of the process that the defendant was entitled to attend, and trials conducted by inquisitorial procedure retained something of a confrontational character. The only part of the process that clearly took place in secreto at Reggio was the reading of the charges to the defendant when he or she responded to the initial summons. ${ }^{44}$ If there was an accuser or a party who brought the trial forward ex querela, that party was required to be present before the judge to see the witnesses sworn. Defendants who managed to post surety were warned to appear on the designated day that the witnesses were to give their sworn testimony. ${ }^{45}$ The confrontational nature of some inquisition trials is also suggested by arguments and insults, which occasionally took place between the parties involved during their appearances before the judge. ${ }^{46}$

The testimony of witnesses was by far the most important source of proof for the criminal judge. The testimony of two eyewitnesses constituted a full proof (though not an irrefutable one, as witnesses could be challenged on the basis of their fama). Eyewitness testimony usually resulted in conviction, but having two eyewitnesses testify to a defendant's guilt was quite rare.

Far more often, judges worked with witness testimony and with circumstantial evidence, leaving as an open question the means by which the judge made

\footnotetext{
42 Peter Stein, "Judge and Jurist in the Civil Law: An Historical Interpretation," Louisiana Law Review 46 (1985), 247.

43 Padoa-Schioppa, "La giustizia Milanese nella prima età Viscontea," 17.

44 "In secreto" is not further defined in the statutes. Presumably it referred to the defendant's appearance before only the judge and his notaries.

45 After the defendant gave his or her response and the fideiussor made an oath, the judge set the time allowed for making a defense, and then ordered him or her to appear on the determined day to see the witnesses sworn, "ipsum admonuit quatenus singulis diebus et horis iuridicis debeat comparere ad videndum iurare testes."

46 For example, ASRe, Giudiziario, Libri delle denunzie, July 9, 1398, vol. 18, fols. 18r-21v.
} 
his decision. At Reggio, it happened at times that the judge was moved to conviction with only one eyewitness and no apparent circumstantial evidence. This may underscore Vallerani's reading of Gandinus, which showed that the judge's conscience played a major role in the determination of conviction. ${ }^{47}$ The question of judicial discretion in conviction is addressed in Chapter Five; here, we should consider how the judge's observation of the witness may have influenced his understanding of the testimony, and therefore his decision.

In 1403, Antonius de Albrixiis was accused of hitting Antonius, son of Bartolus de Moncono, and pulling out his hair. The witnesses named against him were Franchischus de Maliveris, iurisperitus, and Franchiscus's son Symon. The defendant answered the summons to appear before the judge, but told the judge a different story: he said that Antonius de Moncono had knocked his own son Jacob to the ground, and Antonius de Albrixiis, crying "I told you to let him [Jacob] go!" (ego bene dicebam tibi quod dimiteres eum!) then grabbed him up, pulling out a little bit (aliquantulum) of his hair in the process. ${ }^{48}$

The iurisperitus Franchischus, who was a witness against Antonius de Albrixiis, told a different story. According to him, as the boys were quarrelling, Antonius de Albrixiis called out, "Let my son go, before you make him fall on the ground and his head gets broken!" (Dimite filium meum, ne facias eum cadere in terram, quoniam habet fractum caput!) Antonius de Moncono did not listen to him, but threw Jacob on the ground anyway, and bruised his forehead. Antonius de Albrixiis then chased Antonius de Moncono, who tried to run away. The boy made it up two of the stairs to his father's house before Antonius de Albrixiis caught him and pulled out his hair, saying "I very well told you that you should let my son go, and not throw him on the ground!" (Ego bene dicebam tibi quod dimiteres filium meum, et ipsum non prohiceres in terram!) Franchischus told the judge that the boys quarrelling were about eight years old, and that the other two people present were his own son Symon, eight years old, and, confusingly, another boy named Simon, who was seven years old. The judge summoned the young witnesses to gauge their age for himself. He determined by looking at them that they were less than ten, so he dismissed them. ${ }^{49}$ But he convicted the defendant anyway, ordering him to pay a relatively small

47 Vallerani's analysis of Gandinus's views on conscience and arbitrium is found in "Procedure and Justice," $52-57$.

48 ASRe, Giudiziario, Libri delle denunzie, April 28, 1403, vol. 20, fols. 1r-3v.

49 ASRe, Giudiziario, Libri delle denunzie, April 28, 1403, vol. 20, fol. 3v: “... ex aspectu personarum suorum videntur etiam minores decem annorum, dictus Dominus Vicarius et Iudex Maleficorm pronunciavit et declaravit predictos Simonem et Simonem examinandos non esse super dicta inquisitione et contentis in ea." 
fine of 1.10s, even though the only evidence introduced was one legitimate eyewitness. Why?

Keeping in mind Gandinus's contention that the judge can consider, by his conscientia, the nature of the person before him, it is worth noting that Antonius de Albrixiis was no stranger to the criminal court. Unfortunately there is an almost total gap in the trial records from 1399-1402 (only five trials exist from 1402). But from 1403-1407, the records continue, and in them we find Antonius de Albrixiis named in five separate cases: in March of 1403, together with a certain Antonius Guoli, he was serving as captain of his neighborhood of S. Pietro, and in this capacity, before the same judge, he made an unsuccessful denunciation of a certain Antonius de Gypso concerning a quarrel. ${ }^{50}$ In April of that year, the fight described above occurred. In July of that year, he was accused of fighting and quarrelling in a public street (of which charge he was ultimately absolved). ${ }^{51}$ And in 1406 , he was convicted of insulting his brother's wife - the same brother that stood as his pledge when he was accused of beating the boy Antonius de Moncono-for which he was fined 10 pounds. ${ }^{52}$ Also in 1406 , he was denounced for insulting a notary during a court proceeding. ${ }^{53}$ If his subsequent behavior was in any way descriptive of his behavior in the years for which records are lost, it does not seem unlikely that the court was already familiar with his character. One eyewitness should not have been enough to convict him, but perhaps taken in combination with his general behavior, the judge was moved to believe the version of events in which Antonius acting impulsively, beating the child who threw his son to the ground.

Judges necessarily exercised some discretion in weighing testimony. As in Antonius's case above, the judge decided by observation whether the witnesses seemed old enough to testify. Like the insane, the very young could not testify because they were not understood to have the necessary powers of reasoning. ${ }^{54}$ Anyone not under ban could give testimony, and the testimony of women held full weight. All witness testimony had to demonstrate a legitimate basis of the witnesses' knowledge, iusta causa et legitima scientia. This demonstration of the basis of knowledge, discussed in the previous chapter with respect to fama,

$5^{0} \quad$ ASRe, Giudiziario, Libri delle denunzie, March 27, 1403, vol. 19, fols. 56r-58v.

51 ASRe, Giudiziario, Libri delle denunzie, July 6, 1403, vol. 20, fols. 49r-51v and 143-146v.

$5^{2}$ ASRe, Giudiziario, Libri delle denunzie, June 9, 1406, vol. 21, fol. 62r-v.

53 ASRe, Giudiziario, Atti e processi, n.d., 1406, unnumbered folios, discussed above in Chapter Two.

54 Bartolus, Tractatus testimoniorum, ed. Suzanne Lepsius, Der Richter und die Zeugen: eine Untersuchung anhand des Tractatus testimoniorum des Bartolus von Sassoferrato (Frankfurt: Vittorio Klostermann, 2003). 
was central in weighing witness testimony of all kinds, because, "according to nature, nothing exists in the intellect that was not first in the sense[s] ..."55

Because witness testimony was so heavily weighted, the criminal court, always concerned with fraud, severely penalized perjurers. The penalty for giving false testimony could be corporal. From the 1335/71 redaction of the statutes to that of 1392, an increase in the severity of penalties for supplying a false witness and for producing false evidence is apparent. The statutes distinguished between those who produced false witnesses, and those who gave false testimony. ${ }^{56}$ The penalty for anyone producing a false witness before the court in the $1335 / 71$ redaction of the statutes was a fine of twenty-five pounds, which was increased in 1392 to a one hundred pound penalty, and restitution of any damages. ${ }^{57}$ Likewise the statute on giving false testimony was augmented in 1392. The version from the $1335 / 71$ redaction set forth severe penalties for those who gave false testimony and produced false instrumenta before the court, declaring that in any civil or criminal case, a person giving false testimony should be condemned to fifty-five pounds, and if unable to pay, his right hand, with which he had sworn to tell the truth, should be cut off. ${ }^{58}$ The person producing a false instrument was to be penalized twenty-five pounds for the instrument. For the person who produced the false instrument, the penalty was far worse: one hundred pounds for each false instrument produced, and if the fine were unpaid, the amputation of the writing hand. If the forger had produced more than three false instruments, he was to be immolated. ${ }^{59}$

55 Bartolus, Tractatus testimoniorum, “... secundum naturam nil est in intellectu quod prius non fuerit in sensu."

$5^{6}$ ASRe, Comune, Statuti del 1335/1371, fol. 32r, and ASRe, Comune, Statuti del 1392, 152v.

57 ASRe, Comune, Statuti del 1335/1371, fol. 32r and ASRe, Comune, Statuti del 1392, 152v. The 1392 redaction reads: "De pena illius qui falsum testem produxerit. Si quis falsum testem produxerit in aliqua causa civilli vel criminalli puniatur et condempnetur pro quolibet falso teste in libras centum Rexanorum si scienter produxerit et ultra teneatur ad restituendum dampnatum passum."

$5^{8}$ Instrumenta were public documents created by notaries, which were usually witnessed, but which derived their authority from the signum particular to the notary; Marino Zabbia, "Formation et culture des notaires ( $\mathrm{XI}^{\mathrm{e}}-\mathrm{XIV}^{\mathrm{e}}$ siècle)," in Cultures Italiennes $\left(X I I^{e}-X V^{e}\right.$ Siècle), ed. Isabelle Heullant-Donat (Initiations au Moyen Âge) (Paris: Les Éditions du Cerf, 2000), 303.

59 ASRe, Comune, Statuti del 1335/1371, fol. 32r: "Si quis falsum testimonium dixerit in aliqua causa civili vel criminali puniatur et condempnetur in quinquaginta libras Rexanorum. Et solvi non poterit dictam penam ei manus dextra amputetur cum qua iuraverit testimonium. Et quod si quis falsum instrumentum produxerit scienter puniatur pro instrumento vigintiquinque libras Rexanorum. Item si quis falsum instrumentum scripserit in centum libras Rexanorum pro quolibet instrumento puniatur. Et nisi etiam tertium diem post 
These penalties, already serious, were substantially increased in the 1392 redaction of the statutes. The penalty for giving false testimony was raised from fifty-five R.L. to one hundred. The 1392 redaction likewise removed the option for a monetary penalty for a person who wrote a false instrument, and the penalty became entirely corporal. It should be remembered also that the 1392 redaction did not include a general redaction of the criminal law: the intensification of penalties for these crimes was not part of a general revision, but rather, these were specific choices, which probably underscored Giangaleazzo's concern with fraud in the criminal courts. In fact, the 1392 statute added a law concerning the forging of seals and public documents, which mandated capital punishment for anyone who falsified the seal of the Duke of Milan or of the commune. ${ }^{60}$ There is very limited evidence for the enforcement of these statutes, ${ }^{61}$ but the concern inside the statutes was clear. As the primary means of proof, testimony had to be guarded from perjury and falsity.

\section{Medical Evidence and Expert Testimony}

Rarely was physical evidence brought before the court. Occasionally a witness was asked to identify a weapon, ${ }^{62}$ and occasionally written instruments were

condempnationem solvit amputetur ei manus dextra cum qua scripsit. Et si tria vel plura instrumenta inveniatur scripsisse igne comburatur."

6o ASRe, Comune, Statuti del 1392, fol. 152v. The penalty for falsifying a seal was left to the discretion of the judge. A person who falsified other public documentation was condemned to make restitution for the damage caused: "De pena illius qui falsum testimonium dixerit. Si quis falsum testimonium dixerit in aliqua causa civilli vel criminalli puniatur et condemnetur in libras centum Rexanorum et si solvere non poterit dictam pennam ei manus dextera amputetur cum qua iuraverit testimonium. Et quod si quis falsum instrumentum produxerit scienter puniatur pro instrumento in centum libras Rexanorum. Item si quis falsum instrumentum scripsit amputetur ei manus dextra cum qua scripserit et si tria vel plura instrumenta scripsisse inveniatur igne comburatur. Et si quis falsificaverit sigillum vel bulletinum domini nostri vel communis Regii capite puniatur. Si vero falsificaverit sigillum alterius persone vel universitatis puniatur in avere et persona arbitrio potestatis inspecta qualitate facti et personarum. Et eodem modo puniatur qui falsificaverit vel vituperaverit scriptas aliquas communis Regii vel alterius existentes in archivio publico vel ad camera actorum communis Regii et in quolibet casu contentorum in hoc statuto teneatur dellinqueris ad restitutiendum dampnum passo."

61 ASRe, Giudizario, Libri delle denunzie, June 1, 1405, vol. 21, fol. 18r and following, is an example of a prosecution for bearing false witness.

62 ASRe, Giudizario, Libri delle denunzie, December 6, 1392, vol. 14, fols. 159r-16ov. 
produced. ${ }^{63}$ But descriptions of crimes, thefts, injuries, crime scenes and wounds entered judicial consideration through the medium of witness testimony, always impeachable through the usual means of witness fama. The only exception was expert medical testimony, which followed different rules. ${ }^{64}$

By the end of the fourteenth century, the use of formal medical advice in criminal courts was common in northern Italy. We find the practice in Bologna and Venice, where formal opinions, consilia, written by medical professionals survive in abundance. ${ }^{65}$ Smaller towns such as Imola and Forlì near Bologna, probably influenced by the practice of larger cities, used them too. ${ }^{66}$ The physicians who offered professional advice were selected by the court. In thirteenth-century Bologna, the selection was made randomly when the Podestà withdrew one of four names from a bag, ${ }^{67}$ working with a relatively small number of experts. ${ }^{68}$ In Reggio, it seems doubtful that there were many medical professionals to choose from. One of the stated reasons that physicians were publicly salaried was the fear that they might otherwise leave. ${ }^{69}$

For the physicians, aiding the criminal court through the production of consilia was prestigious. The ability to give consilia was a mark of expertise. ${ }^{70}$ These consilia entered the criminal process at different moments: before and during trials, orally and in writing, or even after the conclusion of a trial but

63 For example, ASRe, Giudizario, Libri delle denunzie, September 10, 1392, vol. 14, fols. 114r-129v, and September 24, 1392, fols. 132-146; ASRe, Giudizario, Libri delle denunzie, June 2, 1396, vol. 15, fols. 83 r- $89 \mathrm{v}$.

64 On medical expertise and medical-legal consilia at Reggio Emilia, see Vitiello, "Forensic evidence," $133-156$.

65 Ruggiero, "The Cooperation of Physicians and the State"; Dall'Osso, L'organizzazione medico-legale a Bologna e a Venezia nei secoli XII-XIV (Cesena: O. Addolorata, 1956); Münster, "La medicina legale in Bologna dai suoi albori alla fine del secolo XIv," Bollettino dell'accademia medica pistoiese Filippo Pacini, 26 (1955): 257-271; Edgardo Ortalli, "La perizia medica a Bologna nei secoli XIII e XIV: Normative e pratica di un istituto Giudiziario" in Atti e Memorie: Deputazione di storia patria per le province di Romagna, n.s. 17-19 (Bologna 1969), 223-259.

66 Ortalli, "La perizia medica," 225.

67 Ortalli, "La perizia medica," 239-241.

68 Ortalli, "La perizia medica," 248.

69 ASRe, Comune, Registri dei decreti, reg. 1371-72, September 10, 1371, cf. Chapter One.

70 Chiara Crisciani, "Consilia, responsi, consulti: I pareri del medico tra insegnamento e professione” in Consilium: Teori e pratiche del consigliare nella cultura medievale, eds. Carla Casagrande, Chiari Crisciani, and Silvana Vecchio. Micrologus x. (Florence: Edizioni del Galluzzo, 2004), 260. 
before a formal peace was sworn between the parties. ${ }^{71}$ Sometimes physicians also practiced post-mortem examinations to determine causes of death, using early forensic methods and sometimes performing dissections and autopsies. ${ }^{72}$

Physicians at Reggio had a formal, obligatory role in crime reporting. This reporting could initiate an ex officio inquisition. For example, in 1381, the surgeon Gabriel de Medici gave a written consilium to the judge the day before an inquisition was formed against two men for a violent quarrel, stating that "I saw and treated Bartholomeus de Posanoschis de Cremona, wounded, as it is said, by Francischinus de Aspertis de Cremona, in the right part of the chest with one wound, with an effusion of blood, whence I say and counsel that the aforementioned Bartholomeus will be in good recovery and outside the danger of death, et cetera." 73 The judge brought an inquisition ex officio against both men the next day. It seems safe to assume that this document served as the court's basis for deteriming the charges that were brought against the defendant. ${ }^{74}$

If a medical opinion could form the basis for an inquisition into murder, obviously a great deal of legal power was becoming attached to medical professionals. This raised the issue of fraud. In Bologna by the late fourteenth century, statutes required that two physicians, both over the age of thirty, who had been resident in their community for at least twenty years, should attend post-mortem or physical examinations of crime victims, and attending autopsies was also one of the duties of the criminal court notary. The doctors were required to make their reports under oath to the Podestà or one of his criminal judges, outlining how many wounds they found, and of these how many were

71 ASRe, Giudizario, Libri delle denunzie, October 8, 1393, vol. 14, fols. 269r-27or; ASRe, Giudizario, Libri delle denunzie, June 21, 1389, vol. 12, fols. 133r-137r; ASRe, Giudizario, Libri delle denunzie, Feb. 4, 1393, vol. 14, fols. 163r-v.

72 Ortalli shows that medical-legal consilia were used in injury cases to help the judge fix a penalty appropriate to the case, and in homicide cases, physicians were necessary to determine the lethal wound. Ortalli, "La perizia medica," 226. For autopsy and dissection, see Joseph Shatzmiller, "The Jurisprudence of the Dead Body: Medical Practition in the Service of Civic and Legal Authorities," Micrologus vir (Florence: Edizioni del Galluzzo, 1999), 223-230.

73 ASRe, Giudizario, Atti e processi, October 16, 1381, fol. 391r: "Conscilium [sic] mei Gabrielis de Medici Ciroytum super eo quod vidi et medicari Bartholameum de Posanoschis de Cremona vulneratum per Francisschinum de Aspertis de Cremona ut dicitur in parti destreori pectoris uno vulnere cum sanguinis effuxione unde dico et consulo predictum Bartholameum fore in bona convalescacia et extra periculum mortis ex predicto vulnere et cetera. Et ego Gabriel de Medicis Ciroychus propria manu superscripsi."

ASRe, Giudizario, Libri delle denunzie, Oct. 16, 1381, vol. 6, fols. 89r-9ov. 
mortal and how many not. Their reports were to be accepted unless evidence could be produced to the contrary. ${ }^{75}$ No statutory directions for medical professional conduct exist at Reggio. However, though there was a relatively small number of medical professionals at Reggio, it is not unusual that the medical consilia were signed by two of them. This was probably a measure to prevent fraud, a perpetual concern of the court.

Professional post-mortem examinations occurred at Reggio Emilia, as they did elsewhere in northern Italy. From their origins in ecclesiastical canonization proceedings ${ }^{76}$ autopsies and dissections were a growing part of the medical curriculum in universities, and were increasingly used in courts of law. ${ }^{77}$ Autopsies were used by the criminal courts of Bologna ${ }^{78}$ and Venice ${ }^{79}$ by the fourteenth century, and these involved some elements of dissection, and sometimes even exhumation. By the thirteenth century, Bolognese officials were ordering the examination of bodies, and wounds were measured and inventoried, and their severity ascertained through examinations that included measuring the depth of cuts with wax candles or fingers. ${ }^{80}$ In late fourteenthcentury Bologna, statutes decreed that these post-mortem exams were to be performed the same day the report of a suspicious death was received, unless the injury and death occurred outside the city walls, in which case the doctors were sent to see the body of the murdered person within three days, before it was handed over for burial. ${ }^{81}$

75 Archivio di Stato di Bologna, Statuti, 1389 vol. fol. 28or-v (hereafter ASB, Statuti).

76 Katherine Park, "Holy Autopsies: Saintly Bodies and Medical Expertise, 1300-160o" in The Body in Early Modern Italy, eds. Julia L. Hairston and Walter Stephens (Baltimore: Johns Hopkins University Press, 2010), 63.

77 Katherine Park, The Secrets of Women: Gender, Generation, and the Origins of Human Dissection (Zone Books, 2006) 52-3. For an investigation of dissection as it developed in Renaissance Venice and its use as a didactic tool, see Cynthia Klestinec, Theaters of Anatomy: Students, Teachers and Traditions of Dissection in Renaissance Venice (Baltimore: Johns Hopkins University Press, 2011).

78 Katherine Park, "Relics of a Fertile Heart: The 'Autopsy' of Clare of Montefalco" in The Material Culture of Sex, Procreation and Marriage in Premodern Europe, eds. Anne L. McClanan and Karen Rosoff Encarnaciòn (New York: Palgrave McMillian, 2002), 118.

79 Shatzmiller, "The Jurisprudence of the Dead Body," 229.

8o Shatzmiller, "The Jurisprudence of the Dead Body," 244. Medical opinions, whether delivered in the form of a certificate or given by a specialist during questioning, were in northern Italy and in southern France not considered testimony but were understood as expert opinions, much as legal consilia were admitted in the municipal civil courts.

ASB, Statuti, 1389, fol. 28or-v. 
The statutes at Reggio neither required nor regulated post-mortem examinations, and in fact, the court at Reggio was perhaps equally likely to rely on lay witnesses to determine cause of death. In the surviving records, lay witnesses who had viewed bodies - those who discovered them, guards who examined them, women who prepared them for burial-were solicited to provide evidence about the cause of death. But the professionalization of medical expertise was certainly underway by the fourteenth century, and at Reggio, there is some indirect evidence of professional post-mortem examination. A document recording the torture of certain murder suspects, accused of killing a man by beating him in the head with swords, describes the wounds inflicted on the victim, concluding that "on account of the aforementioned wounds, the said Peter was and is dead, and Magister Petrus, medicus, says that he is dead because of the aforesaid wounds." 82 There is no mention of this post-mortem examination in the trial process.

Physicians provided their opinions to the judge at Reggio, sometimes in writing, and sometimes by appearing personally to testify. But their testimony was not regular witness testimony. ${ }^{83}$ They were not included in witness lists even when they appeared before the judge during the trial to give their findings orally, underscoring the particular nature of their testimony as expert advice. For Bartolus, always mindful of the basis of knowledge, if "a witness said something is true, because he believes it," that witness is to be discredited. But Bartolus specifically excluded those trained in medicine from this judgment, because "they are not really witnesses, but rather they are like judges accepted to judge an article of a case..." ${ }^{\prime 84}$

The advice of these experts, and their "epistemologically weak but socially powerful" knowledge, ${ }^{85}$ held strong influence in the criminal courts. But, as

82 ASRe, Giudiziario, Atti e processi, August 14, 1373, fol. 161r: “... pro quibus superscriptis feritis superscriptus Petrus mortuus fuit et est et magister Petrus medicus dicit quod mortus est pro superscriptis feritis."

83 Jole Agrimi and Chiari Crisciani, Les Consilia Médicaux, French trans. of Italian text by Caroline Viola (Belgium: Brepols, 1994), 97.

84 Bartolus, Tractatus, 240-241: “Testis dixit aliqua vera esse, quia sic credit. Eius dicto standum non esse ab omnibus responsum est..., magis enim iudicat quam testatur, nisi causam propter qua credit sufficientem adnectat. Nec hiis contradicit quod in hiis, que consistunt in artis peritia, medici, obstetrices et similes de credulitate deponunt. Non enim sunt proprie testes, sed magis ut iudices adsumuntur ad illum cause articulum iudicandum..."

85 Silvia De Renzi, "Medical Expertise, Bodies and the Law in Early Modern Courts," Isis 98 (2007): 322 . 
Mario Ascheri has discussed, their use opened the door to some difficult legal problems. Could a defendant challenge their findings, as he or she might challenge other witness testimony, or seek other experts with more favorable opinions? Johannes Andreae took up exactly this point in his additio to Durantis's text, relating the problem of the false doctors to that of false witnesses or the introduction of forged instrumenta. Yet all medical experts testified to their belief and understanding of events that could not be proven otherwise, and if a second set of experts were consulted, they could be as right or wrong as the first. ${ }^{86}$ The point was especially difficult because it had implications for the juridical consilium sapientis: like the legal consilium, the medical consilium was solicited by the judge and for his use to determine a right course of action, but its probatory value was ambiguous.

As with the problem of torture, the nature of recordkeeping makes it impossible to know how often judges consulted with medical professionals. They are mentioned only occasionally in the trial records. ${ }^{87}$ Yet they were clearly sometimes used in cases where they were not mentioned, because some consilia survive in documentary form, and the corresponding trial record has no mention of them. ${ }^{88}$ Still, the fragmentary evidence that does exist, in parallel with the common practices of other northern Italian towns, suggests that medical professionals participated in the denunciation of crime, in trials, and in postmortem examinations. Their status as witnesses constituted a unique category of expert witnesses, which was much harder for a defendant to discredit.

86 Johannes Andreae, additio ad v. Noscunt, in Ascheri, “Consilium sapientis, perizia medica et 'res iudicata', 535 n. 5 . As discussed by Ascheri, "Consilium sapientis, perizia medica et 'res iudicata', 539-541, this problem received attention not least because of parallels to the use of juridical consilia sapientis: "Subdit etiam quod si iudex ad dictum medici dicentis vulnus Titii cum plures vulneraverunt fuisse mortalem condemnavit Titium de occiso, qui Titius dicens medicum falsum dixisse petit ante sepulturam peritiores medicos adhiberi. Quod factum est, et illi referent illius vulnus non fuisse mortale retractabitur sententia sicut dicitur de lata per testes falsos vel instrumenta, C. si ex falsis instrumentis l. Falsam, et l. finali ff. de re iudi. L. Divus, supra de exceptione Cum venerabilis ...”.

87 For example, in ASRe, Giudizario, Libri delle denunzie, June 11, 1374, vol. 11, fol. 118r; ASRe, Giudizario, Libri delle denunzie, June 21, 1389, vol. 12, fols. 92v-94v; ASRe, Giudizario, Libri delle denunzie, August 20, 1389, vol. 12, fols. 133r-137r; ASRe, Giudizario, Libri delle denunzie, February 4, 1393 vol. 14, fol. 163r-v; ASRe, Giudizario, Libri delle denunzie, Oct. 8, 1393, vol. 14, fols. 269r-27or.

88 For example, in ASRe, Giudiziario, Atti e processi, Oct. 16, 1381, and October 20, 1381, fols. $391 \mathrm{r}$ and 392r. 


\section{Protections in Municipal Law and the Right to a Defense}

The municipal statutes set forth a clear ordo (procedural order) to be followed in criminal procedures which included allowance of a defense for the accused, and guaranteed defendants a period of time in which they could prepare a response to charges made against them. The redactions of the statutes from 1335, 1392, and 1411 begin the Liber de malleficiis et malleficiorum with an ordo iuris for criminal process, "[which] procedure [ordinem] should be observed in criminal matters and criminal processes of criminals, so that it should apply to whoever stands accused, denounced, or inquired against for a crime in a case of wrongdoing before the Lord Podestà or his judges." ${ }^{89}$ This statute guaranteed the process of law to all defendants in the criminal court and limited judicial power, providing both implicit and explicit protections for defendants. ${ }^{90}$

The statutory requirement that the accuser, denouncer, or notifier must provide surety and swear to the veracity of the charge even in inquisition trials was an effort to protect individuals from calumny. ${ }^{91}$ The defendant was entitled to receive a written copy of the accusation. If the cited defendant appeared before the judge, the charges were read and explained in the vernacular. The defendant heard these charges explained privately, in secreto. He or she then took an oath to tell the truth about the charges, and to respond to the charges (se purget) by affirming or denying them. ${ }^{92}$

89 ASRe, Comune, Statuti del 1335/1371, fol. 25r: "In maleficiis et maleficiorum processibus talem ordinem duximus observandum ut quemcumque enormiter aliquem accusari denunciari vel inquiri pro quocumque maleficio et maleficii causa coram domino potestate vel eius iudicibus contingerit."

9o This was in keeping with juridical thought, which gave great weight and consideration to the rights of defendants and the limits of the power of a prince to act outside the law. For a discussion of rights and natural law in medieval due process, see Pennington, The Prince and the Law, 132-164.

91 ASRe, Comune, Statuti del 1335/1371, fol. 25r: "Eaque sic recepta et iurata in actis conscribatur et ea conscripta citetur per nuntium communis personaliter vel ad domum accusatus denunciatus vel inquisitus mandato potestis vel iudicis ut certa die vel hora diei compareat coram ipso potestate vel iudice defensurus se ab ipsa accusatione denunciatione vel inquisitione."

92 ASRe, Comune, Statuti del 1335/1371, fol. 25r: "Et siquidem comparuerit lecta et vulganter exponita in secreto apud iudicem ipsa accusatione denuntiatione vel inquisitione ipsi accusato denunciato vel inquisitio iuret dicere veritatem et se purget a predictis affirmando vel negando..." 
That the accused had the right to a defense is manifest in municipal statutes. The 1411 redaction leaves no room for doubt on this subject, guaranteeing the defendant an opportunity to answer the charges under the rubric, "Concerning the defense given to an accused before condemnation:"

Neither the Podestà nor his judge — either of them — or any other one of their officials exercising jurisdiction can or should condemn anyone in a criminal case on any occasion unless first he gives to this condemned man a sufficient delay to defend himself, which delay cannot be less than three days, but rather he may be given more, after the quality of his person and the magnitude of his business is considered. This delay must be written in the acts. And if [the official] does otherwise, the condemnation has no validity, nor can it stand, but by law it should be considered as nothing... ${ }^{93}$

The length of the delay was left to the judgment (arbitrium) of the magistrate, but the statutes impose a minimum delay of three days. If this right were violated, any condemnation would be invalidated. The delay could not have been too extensive, because the process was constrained by the fact that criminal trials could not continue for more than six months.

The established delay of three days to prepare a defense was given to accused who confessed their guilt as well as to those who denied it: confession did not abrogate the need for the delay, nor did it prevent the defendant from offering a defense. This is because defenses could aim to demonstrate not just the innocence of the accused, but — and more frequently—defendants could also prepare a legal argument against the validity of some aspect of the charge, the court, or the accuser. They could also construct an argument for a reasonable excuse for criminal behavior when the actions themselves were undeniable. These technical exceptions to elements of the charges were called exceptiones and were among the most frequently employed defense strategies.

93 BSR Statuti, ms. 77, fol. 53r: "De defensione danda reo ante condempnationem. Potestas et eius iudex malleficorum vel alter ipsorum seu aliquis alius eius officialis exercens jurisdictionem non possint neque debeant aliquem seu aliquos criminaliter condemnare aliqua occaxione nisi prius dederit tali condemnato competentem dilationem ad se defendendum que dillatio non possit esse minor trium dierum sed dari posit maior inspecta qualitate persone et magnitudine negocii. Que dillatio scribi debeat in actis. Et si contrafactum fuerit, talis condemnatio non valeat nec exigi posit sed ipso iure sit nulla...." 
Evidence offered in favor of the defendant had to be admitted by the court. Under the rubric Quod capitula inteligantur esse admissa ipso iure, ${ }^{94}$ the judges were specifically required to receive as evidence any written materials or instruments that were presented, either as proof of a charge or as a defense. ${ }^{95}$ Once again, the statutes required that the judge allow a defendant time to prepare a defense, and that he hear the defense and consider any evidence produced before him. Violating these rules nullified a judgment.

\section{Responses: Confessions, Denials, and Exceptions}

The surviving records do not distinguish between defendants who appeared of their own accord, and those who were captured and compelled to appear. Whatever the circumstances of their appearance before the court, the defendants, once before the judge, were entitled to have the charges against them communicated to them in the vernacular. At that point, defendants either confessed or denied the charges. At Reggio, approximately 71 percent of defendants who answered the citation confessed to the crimes they were charged with, while 28 percent denied all or part of the charges against them. ${ }^{96}$

The defendant's initial response before the judge was not binding. Nor is it possible to know at what stage torture entered the interrogation. Whether they confessed or not, defendants were allowed a period of time in which to make a defense. At that point, confessed defendants could retract their initial confession if they wished. For example, in 1386, a member of the city council who stood accused of adultery confessed when he appeared before the judge, but the next day his lawyer appeared in court and announced that the accused had in fact made a mistake when he confessed, claiming that he had done so pro errore and contra omnem veritatem. ${ }^{97}$ More commonly, defendants confessed but then made a defense based upon legal, technical exceptions to the nature of the charge against them. Their initial confession did not always mean conviction, though it usually did: of those cases where the defendants initially confessed and the outcome is known, about 94 percent were convicted. Yet denials could be powerful: they did not necessarily lead to absolution, but

\footnotetext{
94 BSR Statuti, ms. 77, fol. $5^{2 v}$.

95 BSR Statuti, ms. 77 , fol. $52 \mathrm{v}$.

96 Based on a sample of 398 cases where defendants appeared and their response is recorded. It is not possible to tell from these records whether the defendants appeared willingly or whether they had been captured.

97 ASRe, Giudiziario, Libri delle denunzie, October 19, 1386, vol. 8, fol. 49v.
} 
they did dramatically increase the chances of acquittal. Defendants were not condemned in 12 percent of cases overall, ${ }^{98}$ but when defendants denied the charge, slightly more than half, $5^{2}$ percent, escaped condemnation.

When the defendants or their legal representatives returned to court after the delay, their arguments for their defense varied widely in both complexity and strategy. Sometimes defendants simply denied guilt, and in those cases, the charges were proven or not by the weight of prosecution witnesses. More rarely, defendants claimed alternative versions of the facts or claimed alibis. Some defendants denied charges under torture, which led to an automatic absolution. But the most common kind of defenses were technical objections were known as exceptiones.

Defense arguments usually took the form of exceptiones, which were arguments against some element of the process or charge or evidence against the defendant. These arguments were usually based on highly technical issues like jurisdiction or procedural matters, or on objections to prosecution witnesses or to the accuser. These were not arguments directly responding to the facts as presented in the denunciation or querela, but rather, they were arguments against some element of the charge itself. Not surprisingly, the defendants who responded to charges with these highly technical exceptions often had legal representation. Overwhelmingly, the most frequent exception made was that the victim or one of the key witnesses was a person of bad fama, and thus, could not be believed.

\section{Fama and the Defense}

According to treatises like that of Durantis, a defendant could object to prosecution by inquisition if there was no fama of the crime: "If a prelate wishes to proceed to an inquisition against any person, that one against whom he wishes to inquire may object: 'My Lord, by law you cannot inquire against me, because I am not infamous concerning these crimes." ${ }^{\text {99 }}$ Yet the objection that a defendant was not infamous for a crime does not appear in the surviving trials. This may underscore the degree to which inquisitio had absorbed the accusatorial nature of older procedures, which rested on individual accusations. When

98 This number includes convictions based on contumacy.

99 Durantis, Speculum iuris, Book III, Part I De inquisitione §1.1, p. 27. "Si enim prelatus velit procedere ad inquisitionem contra aliquem, opponat is, contra quem vult inquirere: Domine, non potestis contra me de iure inquirere, quia non sum de his criminibus infamatus." 
fama enters into questions of the defense, it is usually based on fama of persons, especially witnesses, but not against the fama that began the inquest. Most often at Reggio, exceptions hinged on proving the mala fama of the accuser or a key witness for the prosecution.

The most common strategy of exceptions was the invalidation of the reliability of the victims or the witnesses for the prosecution by impugning fama. This was a favored defense especially in rape and adultery trials, where the fama of the victim indicated the severity of the crime, and sometimes determined whether a crime had been committed at all. The following four examples will illustrate common defense strategies using exceptions where defendants attempted to prove the mala fama of the victim or of a witness against them.

First we return to the case of Johannes de Cuvriacho and Antonius Tramalius, discussed above with respect to torture. In 1403, Johannes de Cuvriacho and Antonius Tramalius were brought up on charges resulting from a violent quarrel between them. ${ }^{100}$ Antonius hit Johannes twice in the face, knocking out a tooth and causing an effusion of blood, and then he threw Johannes to the ground and struck Johannes with his knees. In return, Johannes struck Antonius with a stone, hitting him but not drawing blood. In the trial that followed, Antonius remained contumacious but Johannes appeared before the court and denied the charges. Three witnesses were named in the denunciation, but when the judge summoned them, only two appeared. Of these, only one, a certain Carolus, claimed to be an eyewitness to the fight. This "halfproof" was not sufficient for conviction but it was enough to require Johannes to prove his innocence through torture. Failure to answer this citation would be contumacy, and Johannes was threatened with the criminal ban. As a result, Johannes answered this charge, but attempted to defend himself-not just from the accusation but from the threat of torture-with a charge of his own, that Carolus was a man of mala fama, and therefore his testimony should be disregarded by the court. The exception consisted of two articles: first, that "Carolus is a man who stays out day and night and converses in the barataria with barateriis, for gambling, and in the taverns with the drunkards, and even spends time in the brothel." The final article was that Carolus's poor reputation was public vox et fama. Johannes's objective was to show that Carolus's word was not sufficient evidence for Johannes to be put to torture. Johannes brought three witnesses to testify that they had seen Carolus in taverns and gambling, and that it was public vox et fama that he did those things. The witnesses testified that they had themselves seen Carolus in these places, and that he lived a

100 ASRe, Giudiziario, Libri delle denunzie, November 3, 1403, and following days, vol. 20,

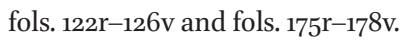


debauched life. Though the record is incomplete, it appears that this exception was successful and Johannes was not interrogated further.

In April of 1387, Caterina de Veneciis and her husband Antonius de Cento brought a complaint against three men, Johannes, Peter, and Luchinus. The men were accused of breaking through the wall of a house where Caterina and another woman, Francesca de Verona, were sleeping. The complaint alleged that these men raped and beat the women and stole certain items from the home. Luchinus was contumacious but Johannes and Peter presented the court with no less than thirty witnesses to testify that the two female victims were of bad fama.

The defendants answered the charges, claiming that they had gone to the home of Caterina, who was a

famous procuress (lene) or ruffian, of dishonest life and shameless behavior, and there they entered the home though the door... and in that home they went to the bed in which a certain Francesca de Verona, a prostitute and known whore (putana), a woman of dishonest life and behavior, was sleeping, believing that this Francesca ought to spontaneously and willingly consent to them just as she was accustomed to consent to others, but since she resisted they knew carnally this same Francesca through force and violence... ${ }^{101}$

The defendants denied breaking the walls of the home, and they denied stealing anything. They admitted rape, but their answer made it clear that they believed Francesca was a prostitute and they expected her to consent. Their defense was an effort to show that the victim was not an "honest woman" but rather was a prostitute. The objective was not absolution-violent rape of a prostitute was still a crime-but rather it was to lessen the charges. The rape of an "honest" woman carried the penalty of death, but the rape of a woman of mala fama was penalized with a fine.

101 ASRe, Giudiziario, Libri delle denunzie, April 5, 1396 and following days, vol. 15, fol. 4or-v: “... inerunt ad domum habitatam cuidam Caterane de Veneciis habitatricis civitatis Regii in vicine Sancti Laurentie famoxe lene seu rufiane vite inhoneste et conversationis impudice et ibi dictam domum intervenerunt per hostium dicte domus et in dicta domo pervenerunt ad lectum in quo dormiebat quadam Francischa de Verona meretrix et putana famoxa mulier inhoneste vite et conversationis credentes quod eadem Francischa eisdem deberet sponte et libenter consentire prout consueverat aliis consentire tamen quia resistebat ibidem eandem Francischam carnaliter cognoverunt per vim ac violentiam ..." 
The exception consisted of three articles:

[The accused] wish and intend to prove through these... witnesses, upstanding citizens of Reggio of good judgment and sound fama, and many others,...that the said Caterina de Venetiis... is a dishonest and shameless woman, ... well known to be infamous, who has dealings with prostitutes and keeps them in her home, and in the past even up to today is regarded as [a prostitute] by all these men who have carnally known her... and concerning this there is public vox et fama in the city of Reggio and especially in the neighborhood of San Laurentus, where Caterina lives. ${ }^{102}$

Item, they wish and intend to prove that the said Francesca de Verona is and was a famous prostitute, living a meretricious life in the city of Reggio for six months or thereabouts, and is a dishonest and shameless woman, and was and is considered and regarded [as such] by all those carnally knowing her. ${ }^{103}$

Item, that concerning each and everyone one of the aforementioned claims, there is public vox et fama. ${ }^{104}$

Each witness was read the articles and asked what they knew about each of them. Because the facts of the rape were apparently beyond dispute, the defendants relied upon these exceptiones to avoid a death penalty.

Exceptions to the credibility of the accuser were not confined to rape trials. On July 20, Johannes, son of Rolandus de Laturre de Argine, was accused by Federichus de Baysio of insulting him:

102 ASRe, Giudiziario, Libri delle denunzie, April 5, 1396 and following days, vol. 15, fols. 42v-43r: "Primo, probare volunt et intendunt per infrascriptos testes viros ydoneos cives Regines bonos opinionis et integre fame et allios multos si expedient et opus fuerit quod dicta Caterina de Venetiis uxor asorta Antonii de cento habitatoris Regii et famosa inhoneste et impudice conversationis lena et infama famoxa cotidie conversationis cum meretricibus et eas in domo tenens et ita fuit temporibus retroneas et ita habita et tractata est huic retro et hodie habetur ab omnibus cognoscentibus eam et de hoc fuit et est publica vox et fama in civitate Regii et maxime in vicina Sancti Laurentei in qua habitat dicta Caterina."

103 ASRe, Giudiziario, Libri delle denunzie, April 5, 1396 and following days, vol. 15, fol. 43r: "Item, probare volunt et intendunt quod autem dicta Francescha de Verona est et fuit famoxa meretrix et unam meretricallem exercente in civitate Regii a mensibus sex citra... et est mulier inhonesta et impudica et ita habita et reputata est et habetur et reputatur ab omnibus eam cognoscentibus."

104 ASRe, Giudiziario, Libri delle denunzie, April 5, 1396 and following days, vol. 15, fol. 43r: "Item quod de predictis omnibus et singulis fuit et est publica vox et fama." 
While the said Federichus in the present year of 1397, on the sixth indiction, in the present month of July, was seeking six gold florins before the said Lord Vicar from Barthinus de la Turre, having come before the said lord, Johannes de la Turre [Barthinus's brother] appeared before the Lord Vicar and said to Federichus ... in the presence of the Lord Vicar, "I gave you two gold florins for this case [already], which Filipus de Pinetis took from you." And then the said Federichus denied that he received these two florins in this case... And then Johannes said injurious words to Federichus, with an angry heart and a wicked manner, and with an aim and intention of harming Federichus: "You are not a good man, as you deny that you received this gold in this case," Which words brought and bring Federichus to insult. 105

This insult was committed before the judge, in the courtyard of the residence of the Podestà. A second charge follows:

Item, that ... Johannes, after these events, went before the said Lord Vicar after an interval of time and said injurious words to this same Federichus, namely, "You were exiled from this city of Reggio, along with such of your instruments [documents] with which you unjustly made profit of the men of this city."106

105 ASRe, Giudiziario, Libri delle denunzie, July 20, 1398, vol. 18, fol. 25r: "In eo, de eo et super eo ... quod dum dictus Federichus de anno presenti 1398 indictione vi de presente mense Iulii peteret coram dicto domino vicario Berthino de la Turre constitutus coram dicto vicario florenos sex auri dictus Johannes de la Turre constitutus coram dicto domino vicario dixit eidem Federicho presenti et in presentia dicti domini vicarii, 'Ego tibi dedi detum [sic] de causa florenos duos auri quos tibi minavit [minuit] Filopus de Pinotis,' et tunc dictus Federichus se recepisse negavit ipsos duos florenos dicta de causa inquisitionis appareret ipsos duos florenos recepisse et tunc dictus Johannes dixit eidem Federicho irato animo et malo modo et animo et intentione ipsum Fredrichum iniurandi infrascripta verba iniuriosa, videlicet, 'Tu non es bonus homo in negando id quod tu recepisti aura superscripta,' de causa que verba idem Federichus sibi provocavit et provocat ad iniuriam."

106 ASRe, Giudiziario, Libri delle denunzie, July 20, 1398, vol. 18, fol. 25v: "Item... quod superscriptus Johannes post superscripta per spatium et temporis intervallum existens coram prefacto domino vicario irato animo et malo modo ac animo et intentione ipsum Federichum iniurandi dixit eidem Federicho superscripta verba iniurosa, videlicet, 'Tu fuisti deschatiatus de hac civitate Regii cum istis tuis talibus instrumentis quibus indebite uteris contra homines huius civitatis'” 
Summoned to respond to the charges, Johannes appeared in court and gave his answer: yes, he had spoken as charged, but "he denied, however, that he spoke these words against the said Federichus with an intention of injuring him in any way, but rather, he spoke the truth ..."107 As in the rape trial above, Johannes admitted the act itself. His defense rested on de-criminalizing his behavior, and, in this case, on denying that he acted with the intention of committing a crime.

In his lengthy response, Johannes made many objections to the charges. He claimed that he should be charged with only one crime, and not two, since there was no intervalla temporis between the two statements. He asserted that because the accuser was not present in court to pursue the accusation, the process should not continue. This argument rested on references to the Digest and also on the example of Christ: "whence it is read that Christ said to the woman, if no one accused you, I will not condemn you." ${ }^{108}$ While to speak injurious words is indeed a crime, he argued, the case should not proceed by inquisition, ${ }^{109}$ and at any rate, just because he said that Federichus is not a good man, it does not necessarily follow that he is a bad man, so really, he had not insulted him at all. ${ }^{110}$ Furthermore, he argued, the words were taken out of context, as they were spoken in the course of testimony regarding another inquisition, which involved his brother.

The lengthy response, delivered orally before the judge, occupies nearly a complete folio and is filled with citations to municipal statutes, to Scripture, and to Roman law. The articles of the exception were more specific. They focused on the strongest arguments in the response, and provided the framework for the interrogation of witnesses. The exception focused on the character of the witness:

First, that this Federichus de Bayso took and had two florins from Filipo de Pinetis at the request of the said Johannes, ... concerning which, in

107 ASRe, Giudiziario, Libri delle denunzie, July 20, 1398, vol. 18, fol. $27 \mathrm{r}$ and following days: “... negavit tamen ipsa verba dixisse contra superscriptum Federichum animo iniurandi ipsum aliqualiter sed pro veritate..."

108 ASRe, Giudiziario, Libri delle denunzie, July 20, 1398, vol. 18, fol. 27r and following days: "... unde legitur Christum dixisse mulieri si nemo te acuxat nec ego te condempno..."

109 ASRe, Giudiziario, Libri delle denunzie, July 20, 1398, vol. 18, fol. 27r and following days: "... maxime in casu nostro cum crimen iniuriarum sit bene crimen et in talibus nulo modo conceditur de iure procedi per inquisitionem ..."

110 ASRe, Giudiziario, Libri delle denunzie, July 20, 1398, vol. 18, fol. 27r and following days: "Item, non sequitur tu non es bonus homo in negando michi id quod tu recepisti ergo tu es malus homo vel tu non es bonus homo..." 
this inquisition formed against the said Johannes de la Turre, mention should be made of [this payment] to the said Federichus;";1

Item, that Federichus is held and reputed to be a man of wicked lifestyle and fama ... by the men of the city of Reggio who know him ... ${ }^{112}$

Item, that... Federichus was expelled from the city of Reggio on account of his wicked doings and his undue extortions made against men who were obligated to him by notarized documents [per instrumentum] or likewise... ${ }^{113}$

Item, that about each and every one of these matters, there is public vox et fama in the city of Reggio and elsewhere among those men who know Federichus and his reputation. ${ }^{114}$

Johannes provided the court with a list of eight witnesses to testify about the assertions in the exception. The witnesses testified that Federichus had been absent from the city for eight years. Some claimed to have seen him in a castle in the district of Reggio, where he stayed because "he did not dare to come to the city of Reggio." He feared returning because he had sought payment for debts already resolved, and, strangely, because "he killed many horses of the Lord Bishop of Reggio."115 In fact, we can find Federichus as a party or as a witness in at least six previous criminal trials, and in 1389, he was convicted of killing five horses and a mule in the stable of the bishop. ${ }^{116}$ Restitution in this case may have been the debt that caused him to flee Reggio: the trial does not

111 ASRe, Giudiziario, Libri delle denunzie, July 20, 1398, vol. 18, 27r and following days: "Primo, quod ipse Federichus de Baysio percepit et habuit dictos duos florenos de quibus in ipsa inquisitione contra predictem Johannem dela Turre formata sit mentio a Filipo de Pinetis ad requisitionem dicti Johannis soluentis et numerantis ipse Federicho."

112 ASRe, Giudiziario, Libri delle denunzie, July 20, 1398, vol. 18, $27 \mathrm{r}$ and following days: "Item, quod ipse Federichus habetur et reputatur pro homine male conditionis et fame inter et per homines civitatis Regii ipsum Fredrichum cognoscentes ..."

113 ASRe, Giudiziario, Libri delle denunzie, July 20, 1398, vol. 18, $27 \mathrm{r}$ and following days: "Item, quod dictus Federichus alias fuit expulsus de civitate Regii propter suas pravas operationes et indebitas extortiones factas contra homines sibi per instrumentum vel taliter obligatos."

114 ASRe, Giudiziario, Libri delle denunzie, July 20, 1398, vol. 18, 27r and following days: "Item, quod de predictis omnibus et singulis est publica vox et fama in civitate Regii et alibi inter homines ipsum Federichum et eius conditiones cognoscentes."

115 ASRe, Giudiziario, Libri delle denunzie, October 23, 1389 and following days, vol. 13, fols. 85 r-89v: “... quia petebat et exigebat debita instrumenta semel soluta et etiam interfecit plures equos Domini Episcopati Regii."

116 ASRe, Giudiziario, Libri delle denunzie, October 23, 1389 and following days, vol. 13, fols. $85 \mathrm{r}-89 \mathrm{v}$. 
record the amount of the verdict, but one witness claimed that he had been ordered to pay more than two hundred and fifty five florins. ${ }^{117}$

The witnesses also testified to other, similar instances where Federichus had defrauded a debtor, using the courts to force his victims to pay him back twice:

...Federichus sought a certain debt from... Rolandinus, concerning which debt... Federichus had an instrumentum [a document proving the debt.] Which Rolandinus said to Federichus, "I cannot give you the debt right now." And... Federichus said to Rolandinus, "Come immediately before the judge and confess this debt." And thus Rolandinus returned to confess this same debt, making the one debt into two. And [Federichus did this] with a mind and intention of deceiving and defrauding Rolandinus, and seeking this debt twice. ${ }^{118}$

This information was given in response to the third and fourth points of the exception. In this instance, the witness was attempting to establish that Federichus had a pattern of defrauding those who were indebted to him, just as, Johannes claimed, he had done to him.

In this case, the facts themselves were not in dispute. Johannes had confessed to everything in the accusation; his argument in the exceptions was simply that he had spoken truthfully and therefore could not be punished. Federichus responded by making arguments against the arguments in the exceptions, claiming that he had been exiled not because of extortion, but because he was Bolognese and the commune was at war with Bologna. ${ }^{119}$ The judge believed this but on all other points he was persuaded by Johannes's exceptions and the witnesses who testified to them, and he ultimately absolved Johannes from everything except his remark that Federichus was exiled from the city.

117 ASRe, Giudiziario, Libri delle denunzie, October 23, 1389 and following days, vol. 13,

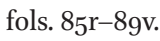

118 ASRe, Giudiziario, Libri delle denunzie, October 23, 1389 and following days, vol. 13, fols. 85r-89v: “... Federichus predictus petierat quoddam debitum a dicto Rolandino de quo debito dictus Federichus habebat instrumentum. Qui Rolandinus eidem Federicho dicti dicebat, 'non possum ad presens tibi dare dictam debitum.' Et dictus Federichus eidem Rolandino dixit, 'venias saltem coram iudice et confitearis debitum' et sic ipsum Rolandinum redduxit ad confitendum idem debitum faciendo dictum debitum esse duo, animo et intentione ipsum Rolandum decipiendi et fraudendi et petendi bis dictum debitum..."

119 ASRe, Giudiziario, Libri delle denunzie, October 23, 1389 and following days, vol. 13,

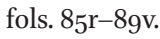


The structure of the presentation of the defense once again shows the oral, potentially confrontational nature of the criminal inquisition. But it also has implications for the issue of judicial credulitas, that process by which the judge was persuaded to rule in favor of guilt or innocence. Why present orally objections to the charges that did not figure into the exceptions, if these arguments had no influence? The rhetorical nature of the oral response suggests that the judge was persuadable, that rhetoric and argument could influence a ruling even outside the scope of technical exceptions (which are often all that remain in the trial records). Once again, an analysis of this trial encourages us to moderate the prevailing view of criminal inquests as technical, largely written processes, and consider the role of both oratory and discretion in judicial decisions.

In this context of the criminal inquisition as a confrontational, public arena, the role of personal enmity in impeaching testimony takes on new dimension. When Antonius, son of Jacobus de Astis, was accused of bearing arms against the order of the Podestà, he responded with a vitriolic objection to the chief witness against him. He claimed that all the witnesses against him were "suspecti et odioxi [Antonio]," but particularly objectionable was Rafaelus de Ollis, who, Antonius claimed, was his enemy. This hatred was one of the grounds for the legal exceptions that made up his defense. He provided witnesses who claimed not only that Rafaelus was inimicus to Antonius but also that Rafaelus had bragged to some men in a tavern that he would destroy Antonius in avere et persona because he was his enemy. ${ }^{120}$ Antonius took the opportunity to solicit testimony to the bad character of his enemy, which surely served the dual function of invalidating his legal credibility in the case against him while also insulting Rafelus, and making their dispute widely known. These were not the only objections Antonius made to the case against him: he also objected to the trial on the technical grounds that the man who accused him had not sworn to the accusation, and for this reason alone the trial should not proceed. His arguments worked in his favor, as eventually he was absolved. Testimony was made public, as were charges and verdicts, and perhaps in cases where long lists of damaging witnesses were brought forward, the parties involved had further agendas for damaging reputation and airing private disputes.

The mala fama attributed to witnesses and victims - which was so often the grounds of a legal exception-is of a different character than the mala fama attributed to defendants. As we saw above, when mala fama is attributed to the defendant in the denunciation, the term seems to denote some sort of

120 ASRe, Giudiziario, Libri delle denunzie, September 5, 1396 and following days, vol. 15,

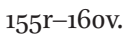


public menace, perhaps in the form of recidivism. But in the case of witnesses, mala fama indicates unreliability. The concept of fama or mala fama is inherently fluid: the same factors that undermine a person in one situation have no bearing in another. Accusations of prostitution, for example, could undermine a victim's complaint of forcible rape. But being a prostitute did not impede a person from standing as witness in the criminal court, or of being legitimately considered as a victim of another crime. When Margarita de Alamania, meretrix publica, was beaten by a German mercenary, the soldier was not only convicted but also swore the peace with her. ${ }^{121}$ When two men were charged ex officio with a violent public quarrel, one of the chief witnesses called by the court to testify was a prostitute. ${ }^{122}$ Mala fama of witnesses was related not to any potential threat they might pose, but to the veracity of their testimony. And so mala fama was a concept most useful for the construction of a defense: public knowledge could acquit as surely as it could convict.

Exceptions constituted perhaps the most important and most effective strategy for defense, allowing the defendant to make an objection to the charges against him on a number of grounds, from highly technical ones to objections to the character of the witnesses for the prosecution. Because verdicts in criminal cases could not be appealed, ${ }^{123}$ exceptions were all the more important, as no legal grounds could be used to gain a new trial. Furthermore it was not uncommon for a verdict, once decided, to be enforced immediately: not infrequently, a capital penalty was ordered and inflicted on the same day. This underscores the importance of the delay allowed to the defendant for preparing a defense.

Some legal knowledge was clearly required to prepare exceptions, and they were usually written by notaries who served as advocates for the defendants. Those without representation still tried to deny or even present defenses, though with very mixed results. One man claimed that he should not be tried for assault because he had already made a peace agreement with his victim. ${ }^{124}$ The judge, unimpressed, convicted him regardless; peace agreements could not abrogate a trial at Reggio Emilia. Other defendants denied charges against them without exceptions. Some of these defendants, in the face of strong

121 ASRe, Giudiziario, Libri delle denunzie, April 8, 1387, vol. 8, fol. 87r-v. Virtually the same scenario can be found again in 1398, where another German soldier struck a German prostitute and was fined 2lb.1os, and swore the peace. ASRe, Giudiziario, Libri delle denunzie, June 17, 1398, vol. 18, fol. 1or-v.

122 ASRe, Giudiziario, Libri delle denunzie, August 27, 1388, vol. 12, fols. 29r-31v.

123 ASRe, Comune, Registri dei decreti, reg. 1385-1425, April 27, 1387.

124 ASRe, Giudiziario, Libri delle denunzie, February 26, 1397, vol. 16, fols. 71r-72v. 
evidence against them, were put to torture. Thomaxius and Bartholazus de Costa, accused of robbing and murdering a traveling merchant, denied their guilt and were put to torture, where they maintained their innocence, and were therefore absolved. ${ }^{125}$ Defendants also presented alternative versions of events, sometimes flatly denying involvement ${ }^{126}$ but more often addressing their defense to elements of the accusation and not to the facts of the case. The relatively high acquittal rate for defendants who appeared in court and denied the charges suggests that defenses of all kinds were successful about half the time.

The statutes and trial records show that defendants had the right to know the charges against them, the right to a delay in which they could prepare a defense, and the right to present that defense to the judge. They could produce evidence, call witnesses, and have legal representation. The methods by which they defended themselves from criminal charges could be very simple or very technical and complex. Allowing defendants to respond to the charges was an integral part of inquisitorial procedure. That they often did so demonstrates further that the late medieval criminal judge operated less as a prosecuting magistrate than as the chair of a fact-finding tribunal.

125 ASRe, Giudiziario, Libri delle denunzie, January 18, 1387, vol. 8, fols. 62r-63v.

126 ASRe, Giudiziario, Libri delle denunzie, February 10, 1397, vol. 16, fols. 67r-7ov. 